УДК 792.82(477)“195/199”

Вакуленко Олеся Михайлівна, доцент кафедри бальної хореографії, Київського національного університету культури і мистецтв

ORCID: 0000-0002-7906-4626 vakusia@gmail.com

\title{
СПЕЦИФІКА ХОРЕОГРАФІЧНИХ ПОСТАНОВОК «А PURO TANGO COMPANY»
}

Мета статті - визначити особливості постановок танго-шоу, в контексті сучасних світових тенденцій розвитку сценічної бальної хореографії, на основі аналізу танцювальних номерів однієї 3 провідних світових культурних корпорацій - мистецької організації «A Puro Tango». Методи дослідження. Застосовано проблемнохронологічний метод, що посприяв вивченню основних проблем та тенденцій розвитку аргентинського танго в хронологічній послідовності; метод компоративного аналізу та порівняльний метод (для визначення відмінностей конституюючих складових у стилі сценічного танго, а також співставлення властивостей його образної мови, виражальних засобів та лексичних особливостей); метод типологізації (для виявлення типологічних ознак жанрів сценічного бального танцю); метод мистецтвознавчого аналізу (для визначення стилістичних особливостей танцювальних номерів мистецької організації «A Puro Tango») та ін. Наукова новизна. Вперше у вітчизняному мистецтвознавстві розглянуто базові для культури танго концепти та їх можливе втілення в музично-пластичній мові сценічної хореографії; охарактеризовано специфіку стилю сценічного танго в умовах сучасного соціомистецького простору; на основі аналізу танцювальних номерів мистецької організації «А Рuro Тango» визначено найхарактерніші для сучасної сценічної хореографії рухи та фігури танго-шоу. Висновки. У системі сценічного бального танцю танго може виступати репрезентантом художнього концепту симбіозу багатьох культур (оскільки поєднує традиції, фольклор, почуття й переживання багатьох народів) та засобом драматургії хореографічної постановки, за умови запрограмування на відповідний сюжет. На основі аналізу танцювальних шоу компанії «А Рuro Tango», можемо визначити, що на сучасному етапі розвитку світової сценічної бальної хореографії, характерними $\epsilon$ зміни конституюючих складових жанру шоу-програм - тематичного простору та форми подачі теми. У хореографічних постановках компанії «А Puro Tango» сценічне танго поєднує різноманітні екзистенційні компоненти метафізичного характеру, що виражають, в умовах даної мистецької форми, специфіку осмислення сучасною людиною життєвих проблем.

Ключові слова: сценічне танго, культура аргентинського танго, «A Puro Tango», хореографічні постановки, концепти.

Вакуленко Олеся Михайловна, дочент кафедры бальной хореографии, Киевский нащиональньій университет культуры и искусств

Специфика хореографическихпостановок «А Puro Tango Company»

Цель статьи - определить особенности постановок танго-шоу, в контексте современных мировых тенденций развития сценической бальной хореографии, на основе анализа танцевальных номеров одной из ведущих мировых культурных корпораций - художественной организации «A Puro Tango». Методы исследования. Применен проблемно-хронологический метод, который помог изучению основных проблем и тенденций развития аргентинского танго в хронологической последовательности; метод компоративного анализа и сравнительный метод (для определения различий конституирующих составляющих в стиле сценического танго, а также сопоставление свойств его образного языка, выразительных средств и лексических особенностей); метод типологизации (для выявления типологических признаков жанров сценического бального танца); метод искусствоведческого анализа (для определения стилистических особенностей танцевальных номеров художественной организации «А Рuro Tango») и др. Научная новизна. Впервые в отечественном искусствоведении рассмотрены базовые для культуры танго концепты и их возможное воплощение в музыкально-пластическом языке сценической хореографии; охарактеризовано специфику стиля сценического танго в условиях современного пространства соціального искусства; на основе анализа танцевальных номеров художественной организации «А Рuro Tango» определены характерные для современной сценической хореографии движения и фигуры танго-шоу. Выводы. В системе сценического бального танца танго может выступать представителем художественного концепта симбиоза многих культур (поскольку сочетает традиции, фольклор, чувства и переживания многих народов) и средством драматургии хореографической постановки, при условии запрограмирования на соответствующий сюжет.

На основе анализа танцевальных шоу компании «A Puro Tango», можем определить, что на современном этапе развития мировой сценической бальной хореографии, характерны изменения конституирующих составляющих жанра шоу-программ - тематического пространства и формы подачи темы. В хореографических постановках компании «A Puro Tango» сценическое танго объединяет различные экзистенциальные компоненты метафизического характера, выражающие, в условиях данной художественной формы, специфику осмысления современным человеком жизненных проблем.

Ключевые слова: сценическое танго, культура аргентинского танго, «A Puro Tango», хореографические постановки, концепты.

СВакуленко О. М., 2019 
Vakulenko Olesya, associate Professor of the Ballroom Choreography Department at the Kiev National University of Culture and Arts

The specifics of the choreographic performances of "A Puro Tango Company"

The purpose of the article is to determine the features of tango show productions in the context of modern world trends in the development of stage ballroom choreography, based on an analysis of the dance numbers of one of the world's leading cultural corporations - the A Puro Tango art organization. Methodology. The problem-chronological method was applied, which helped to study the main problems and development trends of the Argentine tango in chronological sequence; method of corporate analysis and comparative approach (to determine the differences of constituent components in the style of stage tango, as well as comparing the properties of its figurative language, expressive means and lexical features); typologization method (to identify typological characteristics of the genres of stage ballroom dance); a method of art history analysis (to determine the stylistic features of the dance numbers of the art organization "A Puro Tango") and other. Scientific novelty. For the first time in Russian art criticism, the basic concepts for tango culture and their possible embodiment in the musical-plastic language of stage choreography are considered; characterized by the specific style of stage tango in the modern space of social art, based on the analysis of the dance numbers of the A Puro Tango art organization, the movements and figures of the tango show that are characteristic of modern stage choreography are determined. Conclusions. In the system of stage ballroom dance, tango can act as a representative of the artistic concept of the symbiosis of many cultures (since it combines traditions, folklore, feelings, and experiences of many people) and a means of dramaturgy of choreographic staging, provided that it is programmed for the appropriate plot. Based on an analysis of the dance shows of A Puro Tango, we can determine that at the present stage of the development of world stage ballroom choreography, changes in the constituent components of the genre of show programs are characteristic - the thematic space and form of presentation of the topic. In the choreographic productions of A Puro Tango, stage tango combines various existential components of a metaphysical nature, expressing, under the conditions of this art form, the specifics of modern man's understanding of life's problems.

Key words: stage tango, Argentine tango culture, "A Puro Tango," choreographic performances, concepts.

Вступ. Характерним для розвитку сучасного суспільства $\epsilon$ процес модернізації усіх галузей людського життя, що в контексті специфіки сценічної бальної хореографії наразі набуває якостей мистецького феномену і пов'язаний з творчими пошуками, новаторством авторського бачення хореографівпостановників, прагненням до використання нестандартних варіантів втілення ідеї, інтегруванням новітніх технологій та різноманітних способів увиразнення хореографічних творів.

Наразі сценічна бальна хореографія постає як інноваційний тип дискурсу, що на початку XXI ст. зазнає надзвичайних метаморфоз (еволюціонуючи від нерідко епатажних форм розважального напряму до високохудожніх сценічних постановок), пов'язаних передусім із формуванням власних специфічних естетичних засад. У зв’язку з цим актуалізується ії̈ вивчення з позицій сучасного мистецтвознавства.

Мета статті - визначити тенденції розвитку сучасної сценічної бальної хореографії на основі аналізу хореографічних постановок однієї з провідних світових культурних корпорацій - мистецької організації «А Puro Tango»».

Аналіз джерел. У вітчизняному науковому вимірі проблематика сценічного танго, як і загалом сценічного бального танцю лишається на етапі розробки. Окремі аспекти означеного питання побіжно розглядають А. Голубенков, Н. Урсєгова, О. Рудньова, А. Крись та ін. Зарубіжні дослідники висвітлюють особливості танго переважно з позицій культурознавства, наприклад, Ч. Кім «Історія культури танго: історія та культура традиційного танго в Аргентині» [7]; К. Ленг «Аргентинське танго: трансатлантичний танець на європейській сцені» [8]; Е. Тойода «Японське сприйняття аргентинського танго: культурні та гендерні відмінності» [11]; Б. Олжевскі «Тіло танцю: кінетичні та соціальні основи танго» [9].

На основі аналізу вітчизняних та зарубіжних наукових публікацій можемо стверджувати, що проблематика танго-шоу в контексті розвитку сценічної бальної хореографії лишається недостатньо висвітленою і потребує комплексного мистецтвознавчого дослідження.

Виклад основного матеріалу. Художня організація «А Puro Tango» заснована у 2002 p. у Колумбіï відомим танцюристом та хореографом Себастьяном Авенданьо Суаресом 3 метою розповсюдження та популяризації танго. До складу компанії увійшли провідні танцюристи, хореографи та музиканти 3 Аргентини, Уругваю, Іспанії та Росії: А. Уран, Е. Аранго, К. Лейтон, К. Зелейзо та ін.

Хореографічна трупа компанії гастролює в багатьох країнах світу, зокрема, США, Ізраїлі, Росії, Єгипті, Іорданії, Чілі, Аргентині, Еквадорі, Перу та ін., а іiі члени є постіними учасниками престижних чемпіонатів та змагань в категоріях «професійні хореографічні колективи» (наприклад, Міжнародний фестиваль танго Манісалес (Festival Internacional Manizales Tango, 2017 р.), Чемпіонат світу з танго 2013 та 2014 pp; Міжнародний фестиваль танго 2008 та 2009 рр., 8-й Всесвітній саміт танго в Барілоче, Аргентина, Міжнародний фестиваль танго в Пальма-де-Майорці, Іспанія) та «професійне сценічне танго в парі» (Чеміпонат світу з танго 2016 р., Буенос-Айрес, Аргентина).

За безцінний внесок у культуру танго та популяризацію танцю по всьому світу компанію було нагороджено Культурним центром Танго в Буенос-Айресі (2010 р.) та Еквадорським Палацом культури Берджаміна Карріно в Кіто (2013 р.).

Наразі трупа «A Puro Tango» складається з танго-квінтету, вокалістів (Д. Гутьєрреза, К. Усуга) та чотирнадцяти пар професійних танцюристів, переможців міжнародних чемпіонатів та змагань [6]. 
У контексті даного дослідження, вважаємо за доцільне більш детально розглянути деякі аспекти ровитку та популяризації танго.

В Аргентині та Уругваї танго, танець пристрасті, є глибоко вкоріненою традицією, безпосередньо пов'язаною з історією регіону. У жовтні 2009 р. аргентинське танго було визнано Організацією Об'єднаних Націй як частина нематеріального культурного спадку світу.

На думку дослідників, танго стало фоном для швидкого економічного зростання Аргентини, що отримала незалежність після 200-т років іспанського колоніального правління [7, p. 314].

Культура «Танго» розповідає про тяжке становище бідняків у великому, небезпечному, брудному та похмурому районі Ла Бока в першому портовому місті Аргентини Буенос-Айресі, населення якого, відповідно до специфіки іміграційної політики, складали переселенці з сільської місцевості Європи та Аргентини.

Культура танго, що була створена для самозаспокоєння найнижчих верств, а невдовзі перейшла й до вищих, формуючи суспільну згоду, отримала в подальшому розповсюдження у всьому світу (дане явище відоме як «танго-бум»). В умовах соціокультурного простору західноєвропейських країн та в Північній Америці, оригінальну традиційну форму танго було частково перетворено на новий стиль танго [7, p. 314].

У переддень Першої світової війни аргентинське танго набуває масштабної популярності в Лондоні, Парижі та Берліні, ставши одним із найяскравіших «трансатлантичних танців» (поруч із американським регтаймом, 3 характерним синкопованим ритмом), який посприяв глибинним змінам у світовій танцювальній традиції та формуванні стилю сучасного виконання танців. Аргентинське танго стало популярним як сценічний та новий соціальний танець, відіграючи важливу роль в історії сценічної хореографії, ставши, на думку К. Ланг, «унікальним прикладом культурної передачі через прожектори» [8, p.155].

У період репресивних політичних режимів в Аргентині наприкінці 50-70-х та початку 80-х pp. XX ст. танго, як соціальний танець, маргіналізувався, проте з падінням диктатури у 1983 р. та проголошенням демократії в країні, починається період, відомий як «Ренесанс танго». Друга хвиля всесвітнього транскультурного розповсюдження аргентинського танцю була ініційована постановкою новаторського сценічного шоу «Танго Аргентино» («Tango Argentino», прем’єра в 1983 р. у Парижі) під час гастольних виступів на Бродвеї, в багатьох містах Північної Америки, Свропи та Японії [11, p. 165].

Танго - унікальне відображення аргентинської картини світу в своєрідній художній формі, генезис якого визначив безліч етнокультурних уявлень про реальність, зафіксованих в його музично-пластичній мові.

Концептосфера танго, відповідно до визначення поняття концептосфера В. Маслової (сукупність концептів утворює концептосферу як певне цілісне та структурований простір) [2, с. 74], позиціюється як сукупність концептів специфічного культурного простору.

На думку С. Магон, танго, як до речі і румба, - танці, що увійшли до європейської свідомості як жанри 3 еротико-фізіологічним підтекстом, генетично походять від старовинного тьєнто (від ісп. Tiento спокушати; жанр інструментальної музики доби Ренесансу в Іспанії та Португалії) - старовинні тьєнтос стилістично відповідають типовій формі танго [1, с. 187].

Варто зазначити, що сценічне танго (один зі стилів аргентинського танго, призначений для виконання перед глядачами) - постановочне, відоме також як танго-есценаріо, танго-фантазія та танго-шоу, значно відрізняється від танго-салона, танго-мілонгеро або бального танго, характеризується віртуозною технікою виконання складних яскравих фігур, сценічних трюків та певним ступенем театралізованості (особлива видовищність рухів і фігур). У процесі створення постановок, хореограф нерідко поєднує лексику аргентинського танго з акробатичними рухами, підтримками та стрибками, а також синтезує фігури бального танцю з елементами класичного балету та сучасного танцю, гімнастики та фігурного катання. Оскільки соціальне танго (імпровізаційне) виконується проти руху годинникової стрілки довкола танцювального майданчика, деякі рухи постановником адаптовано до умов сценічного простору. Відчувається вплив танго-нуево - окремого напрямку, що вирізняється домінуванням унікальних обертів із сплетінням та виміщенням ніг, вишуканими позами та складними підтримками (особливо популярними $\epsilon$ рухи, в яких партнерка знаходиться поза віссю; «волкада» притулившись один до одного або «колгада» далеко один від одного).

У шоу «A Puro Tango» кроки танцю, характер та почуття визначаються постановником відповідно до музичного супроводу - рухи та малюнок не пов'язані з традиційним танго.

Однією 3 відомих серій танцювальних номерів «А Puro Tango» $\epsilon$ «Життя та Почуття» («Life and Feelings»). Особливою чуттєвістю вирізняються хореографічні постановки «Пристрасть танго БуеносАуйресу» («Passion of Buenos Aires Tango», 2013), «A Puro Tango... Pasión y Sentimiento», «Baile» (2013р.), «Trilogía» (2016 p.), «A Puro Tango - Tour 2018» та ін., на основі мистецтвознавчого аналізу яких можемо визначити найхарактерніші для сучасної сценічної хореографії рухи танго:

- Болео (Boleo) - рух в якому партнер змінює напрям руху, створює імпульс, що змушує вільну ногу партнерки коливатися вздовж підлоги (так зване низьке балео) або, за умови імпульсу з великою енергією, 
піднятися вгору (високе балео). Зміна напряму може виконуватися під час звичного кроку (лінійне болео) та зі скручуванням корпусу танцюристів (кругове болео);

- Болео атре (Boleos atras) - лінійний рух, що призводить до того, що нога партнерки фіксується у повітрі зазвичай позаду тіла;

- Кастіго (Castigatio) - болео вперед, в якому партнерка обплітає опорну ногу партнера;

- Ганчо (Gancho) - pух, в якому нога танцюриста, вдаривши ногу партнера, згинається гаком, що зазвичай відбувається лише при виконанні кроків у напрямку внутрішнього простору партнера;

- П’єрнасос (Piernazos) - високе ганчо, що виконується довкола спини або стегон партнера вільною ногою;

- Сольтади (Soltadas) - фігури, при виконанні яких обійми розриваються: півот партнерки на 360 градусів, проводиться за руку над головою, майже як у Сальсі; обходи партнерами один одного кроками «хіро» 3 продовженням ведення «зі спини» через перенесення ваги; сольтади з обертанням в комбінації 3 іншими фігурами;

- Трепадас (trepadas);

- Сальто (стрибки) та ін.

Варто зазначити, що хореографія сценічного танго «A Puro Tango» включає й традиційні фігури аргентинського танго:

- Очо (ochos) - кроки з обертанням, схожі на вісімку - вперед і назад. Крок у сторону з поворотом корпусу до партнера та розворотом стегон у напрямку кроку. Зазвичай використовується й складна фігура «Очо картадо» (перервана вісімка);

- Кольгада (Colgada) - рух поза віссю обох партнерів з однією віссю посередині. Партнери ніби утворюють літеру « $\Vdash »$;

- Xipo (Giro) - обертання, в якому партнерка обходить партнера, який, у свою чергу, утворює центр обертання. Водночас партнер може також ходити довкола партнерки або вони разом ходять довкола спільного центру;

- Сакада (Sacada) - кроки, в яких один з партнерів уходить у простір іншого, витісняючи його ногу; зазвичай це призводить до того, що вільна нога партнера описує дугу вздовж підлоги.

Оскільки сценічна історія танго сформувала квазі-синкретичну формулу «спів-танець-музичний супровід», сенсовий потенціал танцю в хореографічних постановках «А Puro Tango», розкривається в єдності творчих видів даної тріади. В яскравих сценічних видовищах поєднано всі вираження аргентинського танго (хореографічні постановки побудовані на основі лексики сценічного танго), музика та спів у виконанні віртуозів (репертуар складають характерні оригінальні аранжування різних періодів розвитку танго більш ніж за сто років - Pugliese, Troilo, Gardel та Piazzolla).

Танцювальні номери «A Puro Tango» - невеличкі театральні вистави з власною сюжетною лінією та розв'язкою в фіналі, для яких характерна музичність, пози, підтримки, варіації наприкінці виступу та фінальна поза.

Оскільки процеси концептуалізації латиноамериканської дійсності втілені в аргентинському танго, можемо зробити висновок, що в структуру сценічного танго компанії «A Puro Tango» входять елементи, пов'язані 3 певною когнітивною моделлю, яку можна виявити та осмислити як у власному соціокультурному просторі, так і поза ним. Це уможливлює побудову типології пісенно-танцювальних форм у хореографічних постановках відповідно їх співвіднесення до того чи іншого універсального концепту:

- Арабаль (робітничі райони в яких виник та розвинувся танць, околиці міста з ідентичністю яких безпосередньо пов'язане танго);

- Любовний розпач (специфічна атмосфера танго дозволяє чоловіку емоційно розкритися, виявити глибинність його страждань);

- Еротичне розчарування (сексуальна жага і сум народжений ностальгією за справжнім коханням) [10, p. 14];

- Гендерна проблематика - гендерні ролі в танго відображають культурні цінності Аргентини, такі як мужність - чоловік упевнений у собі, в тому що робить, він надійний, турбується про безпеку, процвітання та щастя своєї жінки; жінка також не пасивна, а іï роль в танці є відображенням аргентинської культури, сильних соціальних норм, що диференціюють ролі відповідно до статі [9, p. 75]. Не дивлячись на те, що чоловік та жінка мають різні обов'язки, вони танцюють як єдине ціле, активно співпрацюючи в процесі створення досвіду ефемерного танцю [9, p. 71];

- Швидкоплинність часу (даний концепт є найважливішим у танго, оскільки в ньому розкривається тематика руйнівного впливу часу на почуття, стосунки та життя);

- Кохання - на думку дослідників, в іспанській мовній свідомості кохання може виступати як невизначений потяг між чоловіком та жінкою («пристрасть або велике почуття, яке одна людина відчуває до іншого») [4, с. 74]; водночас для культури характерним є співвіднесення кохання зі стражданням, ідеалізація предмету та обставин кохання, зв'язок закоханості 3 красою та візуальним сприйняттям, ототожнення кохання з насолодою та щастям [4, с. 74-80]; 
- Смерть - на думку американського психолога Р. Меема, любовні та мортальні концепти в іспанській культурі очевидні: «кохання - це перехресне опилювання смертності та безсмертя...» [3, с. 54-55] - через набуття кохання людина осмислює ідею смертності. Між чоловіком та жінком завжди існує «монотонний спів, заряджений чуттєвістю, що відбувається за одним і тим самим сценарієм: підхід, спокуса, коливання, завоювання, спека, бунт i, нарешті, смерть» [5, p. 33].

Кожен із охарактеризованих вище концептів наділений індивідуальним спектром «стереотипних ситуацій» в танго. Саме реалізація даних стереотипів дозволяє сценічному танго виконувати драматургічну функцію в хореографічній виставі.

Наукова новизна. Вперше у вітчизняному мистецтвознавстві розглянуто базові для культури танго концепти та їх можливе втілення в музично-пластичній мові сценічної хореографії; охарактеризовано специфіку стилю сценічного танго в умовах сучасного соціомистецького простору; на основі аналізу танцювальних номерів мистецької організації «A Puro Tango» визначено найхарактерніші для сучасної сценічної хореографії рухи та фігури танго-шоу.

Висновки. У системі сценічного бального танцю танго може виступати репрезентантом художнього концепту симбіозу багатьох культур (оскільки поєднує традиції, фольклор, почуття й переживання багатьох народів) та засобом драматургії хореографічної постановки, за умови запрограмування на відповідний сюжет. На основі аналізу танцювальних шоу компанії «A Puro Tango», можемо визначити, що на сучасному етапі розвитку світової сценічної бальної хореографії, характерними $є$ зміни конституюючих складових жанру шоу-програм - тематичного простору та форми подачі теми. У хореографічних постановках компанії «A Puro Tango» сценічне танго поєнує різноманітні екзистенційні компоненти метафізичного характеру, що виражають, в умовах даної мистецької форми, специфіку осмислення сучасною людиною життєвих проблем.

\section{Jimepamypa}

1. Магон С. А. Фламенко: история, жанр, концептосфера : дис. канд. искусствоведения : 17.00.02 / Нижегородская консерватория шимени Глинки. Нижний Новгород, 2019. 234 с.

2. Маслова В. А. Введение в когнитивную лингвистику. Москва : Флинта, Наука, 2011. 296 с.

3. Мей Р. Любовь и воля. Актуальная психология. Москва : Рефл-бук, 1997. 384 с.

4. Попов О.В. Концепты эмоций в русском, английском и испанском язиках. Вестник ВГУ. 2007. № 1. С. 74-80.

5. Gazenbeek A. Inside Tango Argentino: The Story of the Most Important Tango Show of All Time. Smashwords Edition, 2014. 270 p.

6. Home. A Puro Tango. URL : https://www.apurotango.com.co/home (дата звернення 14.09.2019).

7. Kim Ch.-Sh. Cultural history of Tango : History and Culture of traditional Tango in Argentina. The History Edycation Review. 2018. Vol. 27. pp. 313-348. DOI: 10.31968/hae.2018.11.27.313.

8. Lange K. The Argentine tango: a transatlantic dance on the European stage. Popular musical theatre in London and Berlin 1890 to 1939. Platt L., Becker T., Linton D. (Eds.). London : Cambridge University Press, 2014. pp 153-169. DOI: https://doi.org/10.1017/CBO9781107279681.012.

9. Olszewski B. El cuerpo del Baile: The Kinetic and Social Fundaments of Tango. Body and Society. 2008. № 14.2. pp. $63-81$.

10. Sábato E. Tango. Discusión y clave. Buenos Aires: Losada, 1968. 220 p.

11. Toyoda E. Japanese Perceptions of Argentine Tango: Cultural and GenderDifferencesEtsuko ToyodaStudies in Latin American Popular Culture, Volume 30, 2012, pp. 162-179. Published by University of Texas Press. DOI: 10.1353/sla.2012.0014.

\section{References}

1. Magon, S. A. (2019). Flamenco: history, genre, conceptosphere. Abstract of Ph.D. dissertation. Nizhny Novgorod : Nizhny Novgorod Conservatory of the name of Glinka [in Russian].

2. Maslova, V. A. (2011). Introduction to cognitive linguistics. Moscow: Flint, Nauka [in Russian].

3. May, R. (1997). Love and will. Actual Psychology. Moscow: Refl beech [in Russian].

4. Popov, O. V. (2007). Concepts of emotions in Russian, English and Spanish. Bulletin of the Voronezh State University, no. 1, pp. 74-80 [in Russian].

5. Gazenbeek, A. (2014). Inside Tango Argentino: The Story of the Most Important Tango Show of All Time. Smashwords Edition [in English].

6. Home. A Puro Tango. URL : https://www.apurotango.com.co/home [in English].

7. Kim Ch.-Sh. (2018). Cultural history of Tango : History and Culture of traditional Tango in Argentina. The History Edycation Review, Vol. 27, pp. 313-348. DOI: 10.31968/hae.2018.11.27.313 [in English].

8. Lange, K. (2014). The Argentine tango: a transatlantic dance on the European stage. Popular musical theatre in London and Berlin 1890 to 1939. Platt L., Becker T., Linton D. (Eds.). London : Cambridge University Press, pp 153-169. DOI: https://doi.org/10.1017/CBO9781107279681.012 [in English].

9. Olszewski, B. (2008). El cuerpo del Baile: The Kinetic and Social Fundaments of Tango. Body and Society, no. 14.2 , pp. $63-81$ [in English].

10. Sábato, E. (1968). Tango. Discusión y clave. Buenos Aires: Losada [in Spanish].

11. Toyoda, E. (2012). Japanese Perceptions of Argentine Tango: Cultural and GenderDifferencesEtsuko ToyodaStudies in Latin American Popular Culture, Vol. 30, pp. 162-179. DOI: 10.1353/sla.2012.0014 [in English]. 